${ }^{2}$ Institut für Physik der Atmosphäre, DLR Oberpfaffenhofen, Oberpfaffenhofen, Germany

\title{
Aircraft icing research flights in embedded convection
}

\author{
T. Hauf ${ }^{1}$ and F. Schröder ${ }^{2}$
}

With 17 Figures

Received February 11, 2003; accepted December 1, 2003

Published online: September 15, 2005 (C) Springer-Verlag 2005

\begin{abstract}
Summary
Results from in-cloud measurements with an instrumented aircraft from an icing research campaign in Southern Germany in March 1997 are presented. Measurements with conventional optical cloud probes and of the ice accretion on a cylinder exposed to the flow show the existence of supercooled large drops (SLD) in the size range up to $300 \mu \mathrm{m}$ simultaneously with severe icing with ice-accretion rates of up to $3.5 \mathrm{~mm} \mathrm{~min}^{-1}$. Nearly all periods with icing, including the ones with severe icing, occurred in mixed-phase convective cells embedded in surrounding stratus clouds. The spatial scales of SLD occurrence, respectively severe icing, ranged between several hundred meters and some kilometers and correspond to the length of the transects through the embedded cells. SLD formed through the coalescence process and were found through the whole cloud depth pointing to a source region near cloud top, in line with the arguments of Rauber and Tokay (1991). No indication of icemultiplication by the Hallet-Mossop process was found, despite of the favorable temperatures for that process. Comparisons of the measured amount of accreted ice with the observed cloud-particle size distributions quite surprisingly indicate that ice accretion is mostly caused by $10-30 \mu \mathrm{m}$ sized drops rather than by SLD. The latter, therefore, appear to be a by-product of a hypothesized liquid water accumulation zone near cloud top which is also the primary cause of the observed severe ice accretion. The results confirm the importance of embedded convection and of mixed phase clouds with high amounts of liquid water and simultaneously occurring SLD.
\end{abstract}

\section{Introduction}

The existence of supercooled liquid water in clouds with temperatures ranging between $0{ }^{\circ} \mathrm{C}$ and $-40{ }^{\circ} \mathrm{C}$ represents a metastable thermodynamic state. Drops may freeze spontaneously upon conditions which are still not fully understood, despite of their fundamental relevance for the precipitation formation process. One special type of spontaneous freezing occurs when an aircraft is flying through a supercooled cloud and drops impinge onto the wing and fuselage and freeze subsequently. The resulting ice accretion on the aircraft poses a severe safety problem as the aircraft performance can be substantially degraded (e.g., Cooper et al, 1984). Ice-accretion rate depends primarily on the liquid water content but also on the drop-size distribution due to sizedependent collision efficiencies of drops and aircraft. As a result of several accidents in the past, the current world-wide scientific discussion in aircraft icing focuses on the role of supercooled large drops (SLD) with diameters of 50 to $500 \mu \mathrm{m}$ or even more as aircraft are not certified for flights in supercooled clouds having a drop size distribution with a mean volume diameter (MVD) larger than $50 \mu \mathrm{m}$. The Federal Aviation Regulation Part 25 Appendix C (Federal Aviation Authorities, 1999) defines probable maximum icing conditions 
expected in winter storms and also gives test procedures aircraft have to comply with for achieving certification for flights in supercooled clouds. Drops with MVD greater $50 \mu \mathrm{m}$, however, were not taken into account. Conventional icing occurs mainly in zones of few centimeters width near a stagnation point. Ice accretes there preferably in layers but it may also form horns and fingers. Due to their inertia large drops of usually more than $50 \mu \mathrm{m}$ in diameter may impact well off behind these stagnation zones (Cooper et al, 1984). Solidification of supercooled water proceeds in two major stages, where in the first, with a time scale of $10^{-5}-10^{-4} \mathrm{~s}$, only a small fraction of the water freezes, while in the second stage the exchange of released latent heat of freezing to the environment leads to a considerably longer time scale of $10^{-3}$ to $1 \mathrm{~s}$ (Pruppacher and Klett, 1997, p. 674). Drops remain semi-liquid during that period of time and may freeze completely first further downstream of their impact location and often well behind the protected zones on wings, propellers and inlets. This process is referred to as run-back icing. The accreted ice not only increases the aerodynamic roughness but also may lead to substantial flow distortion and even flow separation. The latter effect may have been a primary physical cause of the ATR-72 crash near Chicago 1994 (Sand and Biter, 2000). One should also note that any initial substantial flow distortion on the otherwise smooth surface of the wing or other parts of the aircraft, such as, e.g., by a frozen drizzle drop of a few hundred microns in diameter, causes a local stagnation point, which in turn increases the ice accretion there and thus constitutes a positive feed back. Frozen drops grow subsequently to mmsized roughness elements with corresponding decrease of aircraft performance (cf. Fig. 10).

SLD are assumed to grow by a pure coalescence process. This is referred to as the non-classical formation of supercooled large drops, while the classical one denotes a situation where liquid cloud or rain drops fall into a layer with subzero temperatures which results into what is usually known as freezing drizzle, respectively, freezing rain. In this study, only the non-classical formation process is considered. One of the not yet fully understood key questions concerns the nature of the coalescence process itself and the favorable conditions for its occurrence (Vohl, 2000 and references ibid; Rasmussen et al, 2000). This study reports on in-situ measurements under the special conditions of embedded convection where severe aircraft icing and SLD were observed. This atmospheric condition has, to our knowledge, not yet been recognized as favoring SLD formation and/or severe icing. The flights were part of the European Community funded project EURICE on aircraft icing. Within the EURICE project, three aircraft operated independently over the Iberian Peninsula, the North Sea, and Southern Germany, respectively. This study reports on the Southern German flight campaign with the DLR's DO228 research aircraft, near Munich, Germany. Results from the other flight campaigns in the EURICE project are presented elsewhere by Amendola et al (1998).

Most of the SLD observations so far are reported from North America, e.g. by Cober et al $(1995 ; 1996 a ; 1996 b ; 2001 a)$, Politovich (1989) or Rasmussen et al (1992). In 1992, Hoffmann and Demmel (DLR Oberpfaffenhofen) reported SLD and related ice accretion measurement during a flight campaign over Southern Germany. The flights were performed in the same area as those of the current paper and are the first SLD documentation from outside North America.

\section{The flight campaign}

In March 1997, a flight campaign was conducted in Southern Germany with a DO-228 instrumented research aircraft shown in Fig. 1. The aircraft was equipped with two optical scattering spectrometers (FSSP-100ER, diameter range 5-95 $\mu \mathrm{m}$, FSSP-300, range $0.4-20 \mu \mathrm{m}$ ) to measure drop sizes and an optical array probe (OAP-2DC, range $20-750 \mu \mathrm{m}$ ) to determine shapes and phases of the particles, together with a temperature sensor and a Johnson-Williams (JoWi) liquid water probe. The instruments were installed in

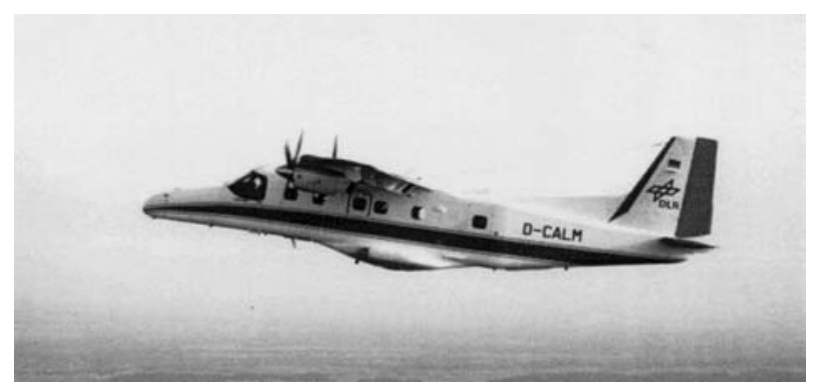

Fig. 1. The DLR DO-228 research aircraft 


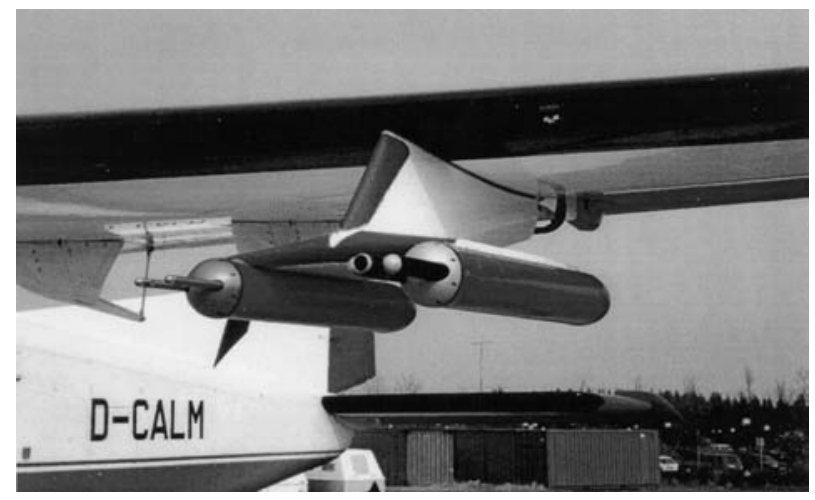

Fig. 2. Cloud microphysical instrumentation mounted on the left wing of the DLR Do-228

metal containers underneath both wings. Figure 2 shows the left wing with the OAP-2DC and the FSSP-100ER. The cloud water content (CWC, water and ice) was compared with the JohnsonWilliams-probe, which measures the liquid water content (LWC) up to drop diameters of $40-50 \mu \mathrm{m}$, and with the cloud-particle volume distributions derived from the optical spectrometers. Two cloud water content values $\mathrm{CWC}_{500}$ and $\mathrm{CWC}_{800}$ were determined, where integration over the particle volume distribution was performed up to 500 and $800 \mu \mathrm{m}$, respectively, including ice and liquid particles. No attempt was made to discriminate liquid from solid particles. Cober et al (2001b), in assessing cloud-phase conditions from various instruments, showed that liquid water content calculations, derived from FSSP based drop size distribution for drops larger $35 \mu \mathrm{m}$ in the presence of ice particles with more than $1 \mathrm{~L}^{-1}$, may show substantial errors. For both reasons calculated integral cloud water contents CWC should be discussed more qualitatively rather than be considered as quantitative measures. Video cameras documented the ice accretion on the wing and on an exposed cylinder of $4 \mathrm{~cm}$ diameter. The cylinder is mounted at the floor of the aircraft and is exposed to the flow with its axis perpendicular to the flow direction. An onboard installed camera looks through a glass window in the floor along the cylinder on to a disc-shaped scale mounted at the end of the cylinder. From the video recording after each flight, both ice accretion (in $\mathrm{mm}$, resolution of $0.5 \mathrm{~mm}$ ) and ice accretion rate (in $\mathrm{mm} / \mathrm{min}$ ) can visually be determined. Please note that the video images (Fig. 3) do not only

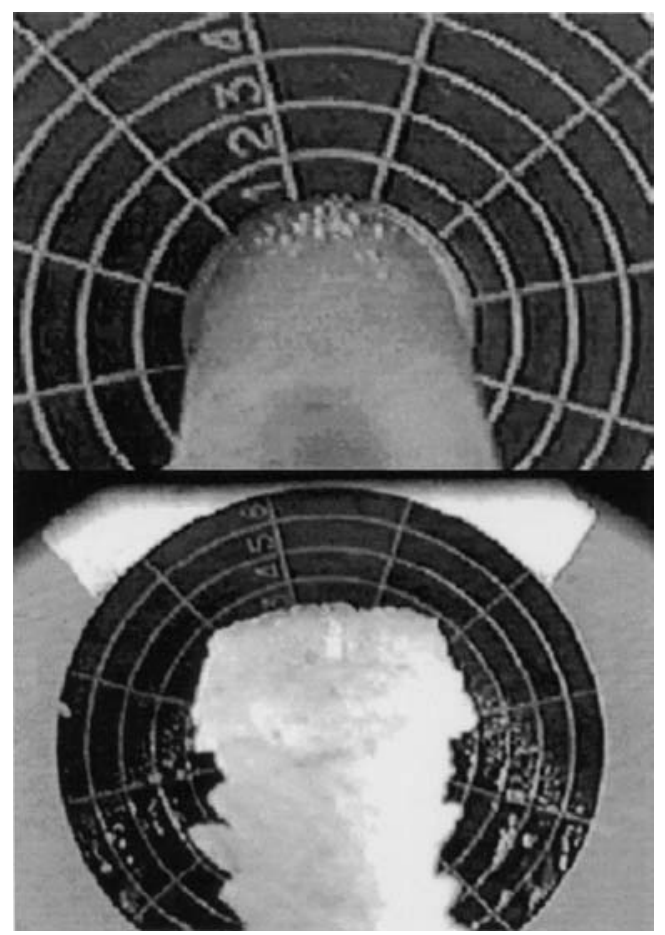

Fig. 3. Video view of the icing cylinder through the glass window in the aircraft floor, flow direction from top (front) to bottom (rear), March 15. Note the bent support in the lower central part. Upper panel: Individual frozen drops are recognizable on the still clean cylinder (9:46 UTC). Lower panel: Ice accretion after a couple of minutes (9:57 UTC). Note the asymmetric ice shape in the lower panel

show ice accretion on the cylinders' flow facing side but also on its bend support (lower central part of Fig. 3). The measurements were made between 15 and 27 March 1997 near Munich, Germany to the north of the Alps. A groundbased Doppler and polarization radar (Hagen and Meischner, 2000), stationed close to the flight path at DLR, Oberpfaffenhofen, monitored the clouds during the flights.

The general weather situation during that period was governed by north-westerly flow, with advection of cold and humid air masses from the North Sea into Central Europe, and by a high pressure system over the Southwest of Europe, which only temporarily expanded into Central Europe. Several low-pressure systems over the North Atlantic moved eastwards and developed branches with their respective frontal systems over Central Europe and the north of the British Isles. Over most part of Central Europe low-level clouds prevailed during the whole flight campaign. In some areas and at some times the cloud 


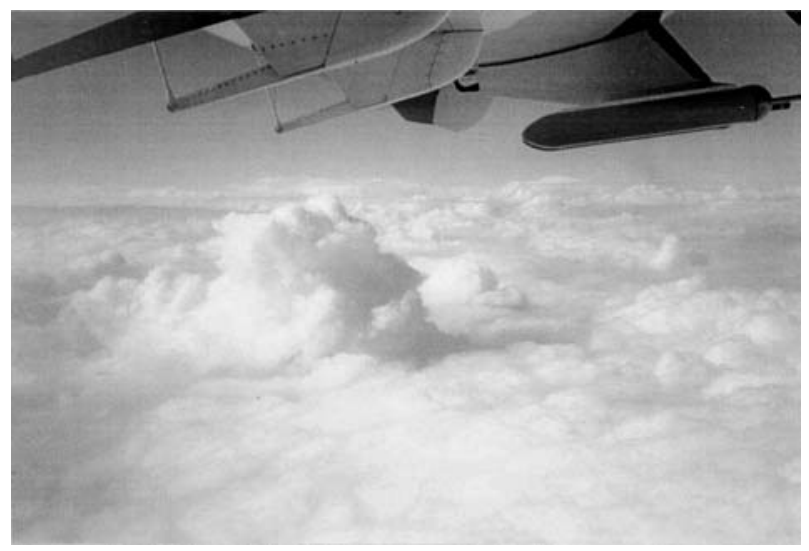

Fig. 4. Upper stratus-cloud deck with an overshooting top of an embedded convective cell on 24 March 1997

field was broken. Usually, convective cells were embedded within the stratus cloud (Fig. 4). They were vigorous and produced occasional rain showers or light rain. The freezing level was mostly in such a height below cloud base that no solid precipitation reached the ground. Cloud fields ranged usually from the North Sea to the Alps. Cloud-top temperatures were rarely colder than $-11^{\circ} \mathrm{C}$. Despite the day-to-day variability in the temperature structure and cloud top and base heights, the convective unstable stratification due to the advection of cold and humid air and lowlevel clouds with embedded and quite vigorous convection were common basic features for the whole period. This weather situation is quite typical for March and April in Central Europe and is in line with the earlier nine year icing studies by Hoffmann and Demmel (1992), where on average the largest number of days with aircraft icing was found in the month of March.

Due to the prevailing weather conditions, the emphasis of this paper is on low-level stratus clouds at sub-freezing, yet relatively high temperatures with embedded convective cells. In Fig. 4 from 24 March 1997 a view from above on the stratiform cloud field is given. Embedded convective cells can be recognized by their tops overshooting the main cloud deck. Vertical temperature profiles from cloud samplings during the initial ascent and the final descent on 24 March are shown in Fig. 5. They reveal a small temperature inversion at the cloud-top altitude, which prohibits further acceleration within the embedded cells and thereby limits the overshooting tops to a vertical extent of approximately $200 \mathrm{~m}$. An aircraft cruising directly above cloud top within this height range alternately encounters cloudy air and cloud-free regions. Occasionally, gravity waves were observed within the upper cloud deck which could be identified by their regular undulations, respectively, the banded cloud structure. This was especially found during flight no. 8 (not shown).

Altogether one test and seven research flights were performed (for details see Table 1). During five of the latter supercooled clouds were sampled and considerable icing was experienced. The focus of this paper is on the two cases with

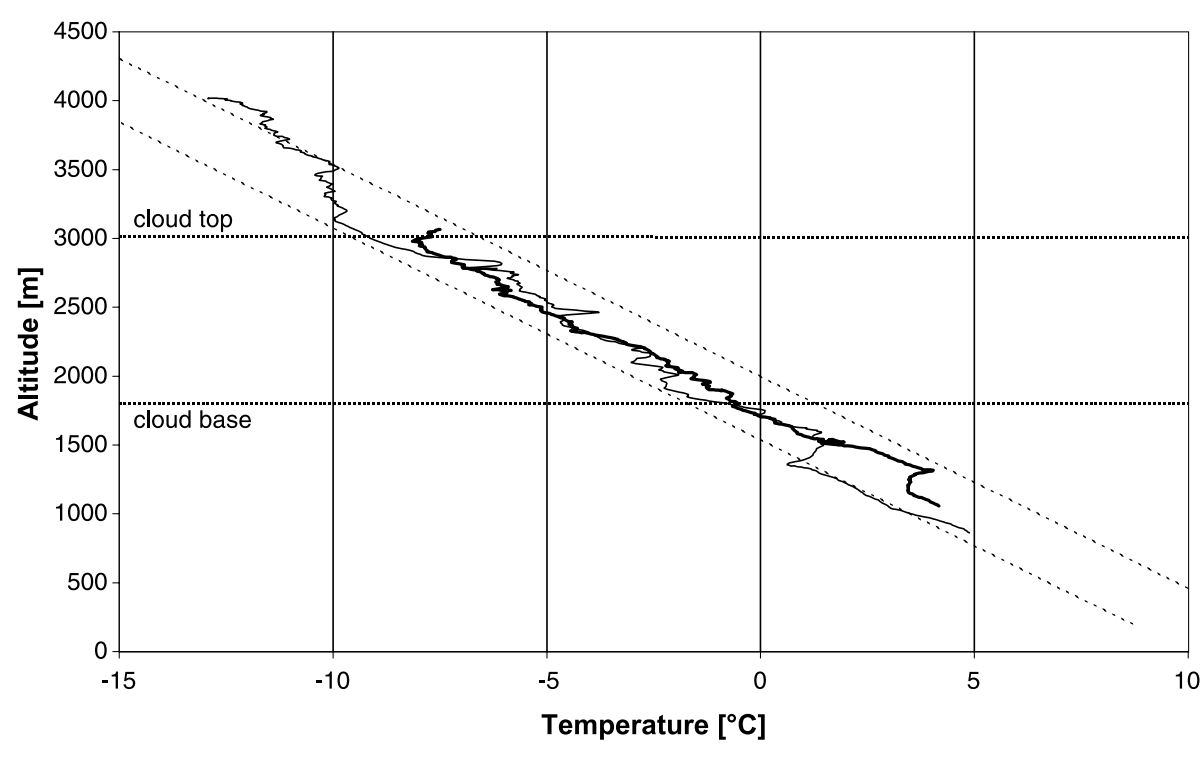

Fig. 5. Vertical temperature profiles on March 24, 1997. The thin solid line represents measurements from the initial ascent, the thick solid line those from the final descent. Dotted lines represent mean wetadiabatic temperature gradients. Average cloud-top and cloud-base altitudes are also indicated 
Table 1. Overview of the eight flight missions

\begin{tabular}{|c|c|c|c|c|c|c|}
\hline Flight number & Date & Time (UTC) & Cloud description & Weather & Icing & Special features \\
\hline 1 & 14 March 1997 & $1502-1530$ & Isolated cumuli & Haze & No icing & $\begin{array}{l}\text { Test flight; no } \\
\text { measurement data }\end{array}$ \\
\hline 2 & 15 March 1997 & 0926-1107 & $\begin{array}{l}\text { Stratus with } \\
\text { embedded } \\
\text { convection, } \\
\text { mixed phase } \\
\text { clouds }\end{array}$ & $\begin{array}{l}\text { North-westerly } \\
\text { flow of moist } \\
\text { arctic air, rain }\end{array}$ & $\begin{array}{l}\text { Severe icing, } \\
\text { SLD }\end{array}$ & No radar data \\
\hline 3 & 18 March 1997 & $1326-1424$ & $\begin{array}{l}\text { Stratus, broken } \\
\text { stratus and } \\
\text { stratocumulus }\end{array}$ & & $\begin{array}{l}\text { No icing, } \\
\text { temperatures in } \\
\text { cloud }>0{ }^{\circ} \mathrm{C}\end{array}$ & \\
\hline 4 & 19 March 1997 & 1040-1259 & $\begin{array}{l}\text { Stratus, embedded } \\
\text { as well as } \\
\text { isolated } \\
\text { convection }\end{array}$ & $\begin{array}{l}\text { North-westerly } \\
\text { flow behind } \\
\text { cold front, } \\
\text { light rain }\end{array}$ & Icing & $\begin{array}{l}\text { No aircraft } \\
\text { data }\end{array}$ \\
\hline 5 & 24 March 1997 & $1030-1300$ & $\begin{array}{l}\text { Stratus with } \\
\text { embedded } \\
\text { convection }\end{array}$ & $\begin{array}{l}\text { North-westerly } \\
\text { flow of moist } \\
\text { arctic air }\end{array}$ & $\begin{array}{l}\text { Severe icing, } \\
\text { SLD }\end{array}$ & \\
\hline 6 & 25 March 1997 & $1317-1436$ & $\begin{array}{l}\text { Cumulus and } \\
\text { stratocumulus } \\
\text { in two layers, } \\
\text { mixed phase } \\
\text { clouds }\end{array}$ & $\begin{array}{l}\text { North-westerly } \\
\text { flow behind } \\
\text { occlusion front, } \\
\text { temporarily } \\
\text { light rain }\end{array}$ & Icing & No radar data \\
\hline 7 & 26 March 1997 & 1344-1509 & $\begin{array}{l}\text { Cumulus and } \\
\text { stratocumulus, } \\
\text { inversion above } \\
725 \mathrm{hPa}\end{array}$ & $\begin{array}{l}\text { weak high } \\
\text { pressure } \\
\text { system }\end{array}$ & Icing & $\begin{array}{l}\text { No FSSP-300 } \\
\text { data }\end{array}$ \\
\hline 8 & 27 March 1997 & $1138-1254$ & $\begin{array}{l}\text { Stratus, gravity } \\
\text { waves with } \\
\text { formation of } \\
\text { drizzle at wave } \\
\text { crests }\end{array}$ & $\begin{array}{l}\text { after warm } \\
\text { front passage } \\
\text { with extended } \\
\text { rain field }\end{array}$ & $\begin{array}{l}\text { No icing, } \\
\text { temperatures in } \\
\text { cloud }>0{ }^{\circ} \mathrm{C}\end{array}$ & \\
\hline
\end{tabular}

moderate to severe icing, March 15 and 24, 1997, while the other days with icing were not deeply evaluated. The results achieved for those days differ in detail, but not with respect to the overall conclusions. The flight patterns consisted of vertically staggered straight and horizontal flight legs approximately $50 \mathrm{~km}$ in length (Fig. 6). The number of legs per flight ranged between 5 and 12. After an initial sounding through the entire depth of the cloud, the latter was surveyed usually from above with penetrations of overshooting tops, if present. Then the cloud was probed level by level. As temperatures below cloud base were always above zero, the aircraft could descend and thaw off the accreted ice in case of severe performance degradation, which happened once. The flights were in the approach area of the Munich International Airport. The flight pattern was checked with air traffic controllers and each flight level change had to be

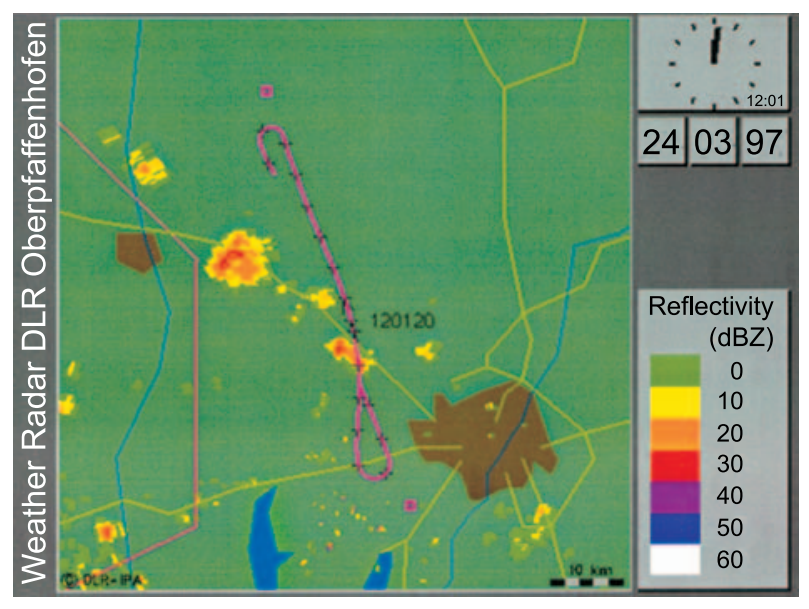

Fig. 6. Example of the flight pattern March 24, 1997. The aircraft flew back and forth along a line approximately oriented NNW-SSE in the region between Munich (right) and Augsburg (upper left) in Southern Germany. The flight path is superimposed on a horizontal radar image (ppi). Crosses mark position of aircraft for every minute. The radar is located halfway between Munich and lake Ammersee further to the west 
requested which led to nonuniform vertical spacing between consecutive flight legs. Due to air traffic requirements not all requested level changes were confirmed. No attempt was made to select other than a straight level flight pattern.

\section{Measurements}

\subsection{The icing flight on March 15, 1997}

After an initial sounding the aircraft performed an overview leg above the cloud layer, at $3400 \mathrm{~m}$, and two in-cloud straight level flights at $3000 \mathrm{~m}$ between 9:52-9:57 and 10:13-10:19, separated by a descent to below cloud base and a subsequent flight leg at $2400 \mathrm{~m}$, just above cloud base at $2300 \mathrm{~m}$. After the second leg at $3000 \mathrm{~m}$ the aircraft ascended further to $3300 \mathrm{~m}$, just below cloud top. A straight level flight was followed by some maneuvers to test the aircraft performance under icing conditions which, however, will not be discussed here. After altogether 32 minutes in $3300 \mathrm{~m}$ a descent terminated the flight. Figure 7 shows the time sequence of liquid water content $\left(\mathrm{LWC}_{\mathrm{JoWi}_{\mathrm{i}}}\right)$, measured with the Johnson-Williams probe, and of ice accretion rate for the whole flight period between 9:30 and 10:40. The former values were smoothed over 3 seconds. The dominant feature of the LWC signal is a relatively low value of $\sim 0.1 \mathrm{~g} \mathrm{~m}^{-3}$ with short bursts of maximum $0.28 \mathrm{~g} \mathrm{~m}^{-3}$ over time periods of minutes, corresponding to spatial scales ranging from several hundred meters to several kilometers. The same feature can be found in the time series of total number of events given by the OAP-2DC (not shown). We will show in the next section that these bursts correspond to passages through convective cells which were embedded in the stratus cloud.

\subsection{Detailed studies of SLD-events - overview}

We focus now on two time sequences of the flight at $3000 \mathrm{~m}$ and $3300 \mathrm{~m}$, in the following referred to as Seq1 (Fig. 8; 9:52-9:57 UTC; left peaks in Fig. 7) and Seq2 (Fig. 9; 10:20-10:28 UTC, middle of right peaks in Fig. 7), with a duration of 4-8 min each, where the aircraft penetrated cloud sections with remarkable icing rates. The temperatures were $-9{ }^{\circ} \mathrm{C}$ in Seq1 and $-11^{\circ} \mathrm{C}$ in Seq2 (see right upper scale of Figs. 8 and 9). Please note that the flight level of $3000 \mathrm{~m}$ was left for descent at about 9:57 UTC $(=9.95$ decimal hours) with a subsequent temperature increase. Similarly, the ascent to $3300 \mathrm{~m}$ in Fig. 9 of Seq2 with the accompanying temperature decrease was completed at 10:22 UTC ( =10.37 decimal hours). Maximum ice-accretion rates of $3.5 \mathrm{~mm} \mathrm{~min}^{-1}$ were experienced during Seq1, where the $\mathrm{LWC}_{\mathrm{JoWi}}$ typically ranged between 0.25 and $0.3 \mathrm{~g} \mathrm{~m}^{-3}$. Focusing now on the two additionally calculated total water content estimates $\mathrm{CWC}_{500}$ and $\mathrm{CWC}_{800}$ for Seq1 in the upper panel for Fig. 8, we recognize first that, as required by their definition but despite of the uncertainties reported by Cober et al (2001b),

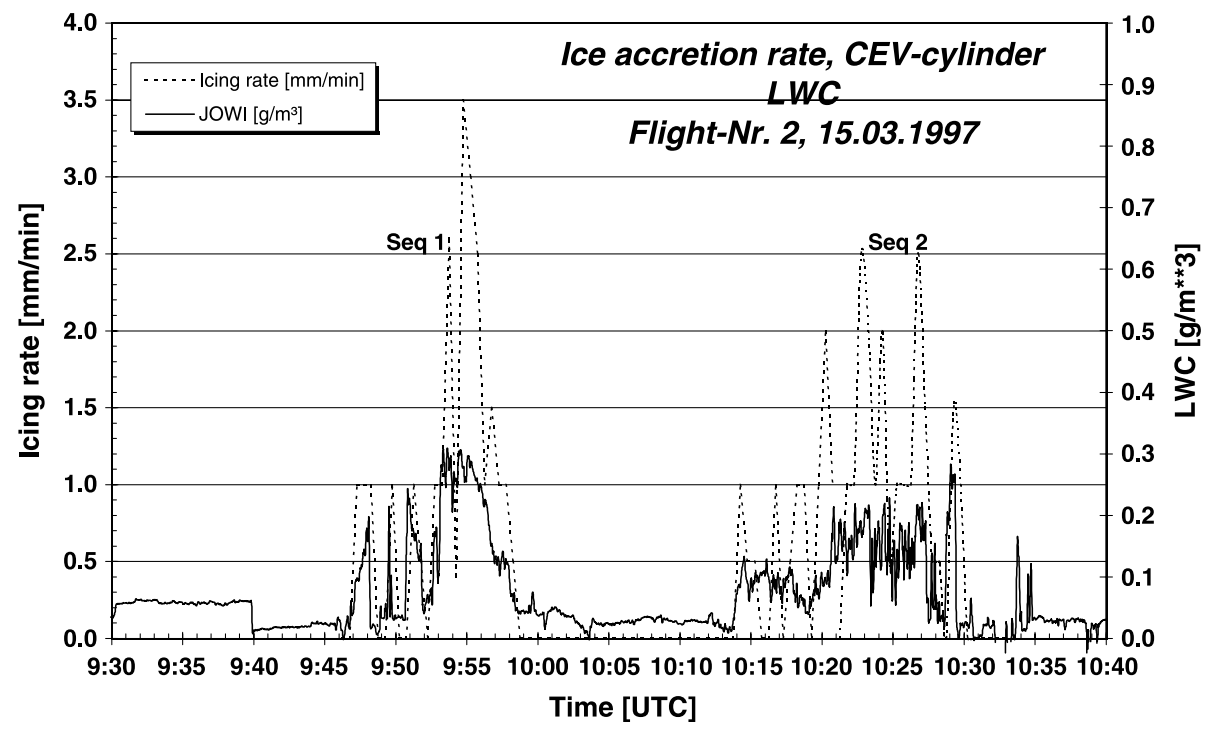

Fig. 7. Ice accretion rate (left scale) and Johnson-Williams liquid water content (JoWi, right scale) for the flight on March 15, 9:30-10:40 UTC 


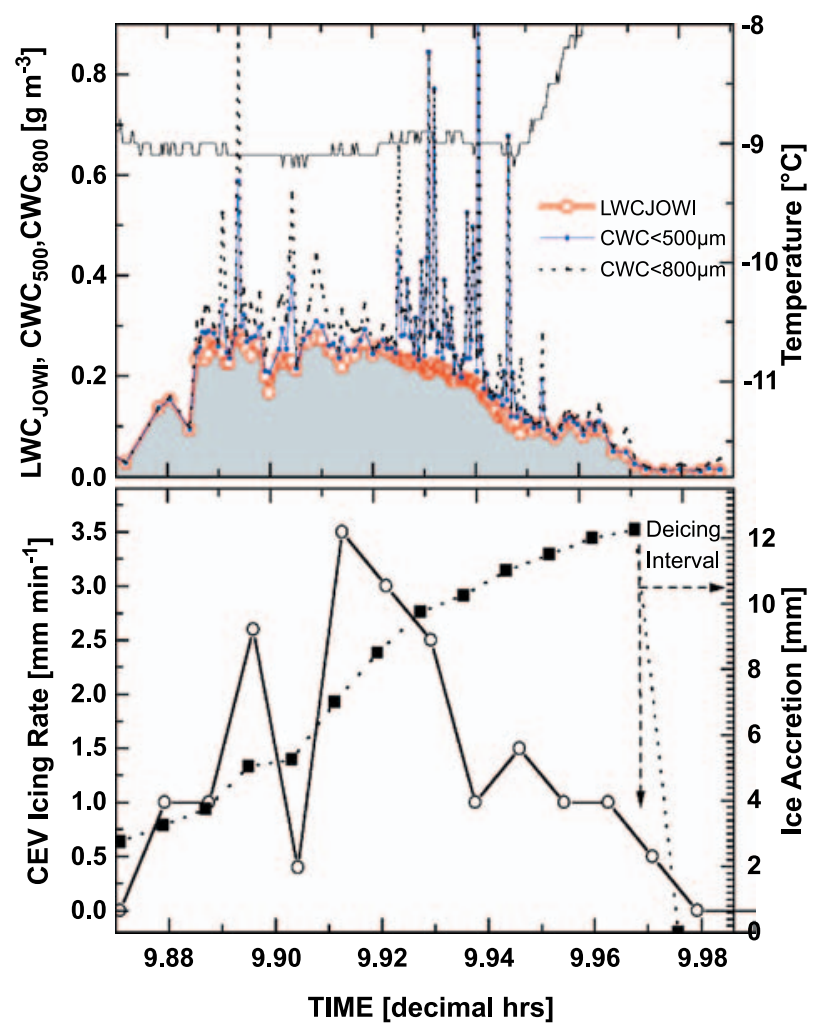

Fig. 8. Icing parameters during flight sequence Seq1 (9:529:57) on March 15: Upper panel: JoWi-LWC (open circles), $\mathrm{CWC}<500 \mu \mathrm{m}$ (solid line) and $\mathrm{CWC}<800 \mu \mathrm{m}$ (dotted line, all left scale) and ambient temperature (step line, right scale). Lower panel: Ice accretion on the cylinder (solid squares, right scale) and icing rate (open circles, left scale). See also text for further details

$\mathrm{CWC}_{500}$ is always smaller than $\mathrm{CWC}_{800}$. The dominant feature, however, is that both quantities peak in small bursts of tens of seconds, respectively, spatial scales between 100 and $300 \mathrm{~m}$, a fact which was noticed already previously for the $\mathrm{LWC}_{\mathrm{JoWi}}$. The photograph (Fig. 10) of the wing underside was taken shortly after the exit from Seq1. Besides ice accretion of more than $10 \mathrm{~mm}$ on the leading edge, a considerable amount of ice was observed on the black rubber panel of the pneumatic deicing boots about $30 \mathrm{~cm}$ downstream of the active and floatable part of the latter. Immediately behind the leading edge streaks of accreted ice can be identified which indicate run-back ice. Further downstream ice accretes as little spots and humps with each of them very likely results from frozen drizzle drops, respectively, SLD grown further by riming.

To emphasize the short scale fluctuations, we have selected ten very short flight segments

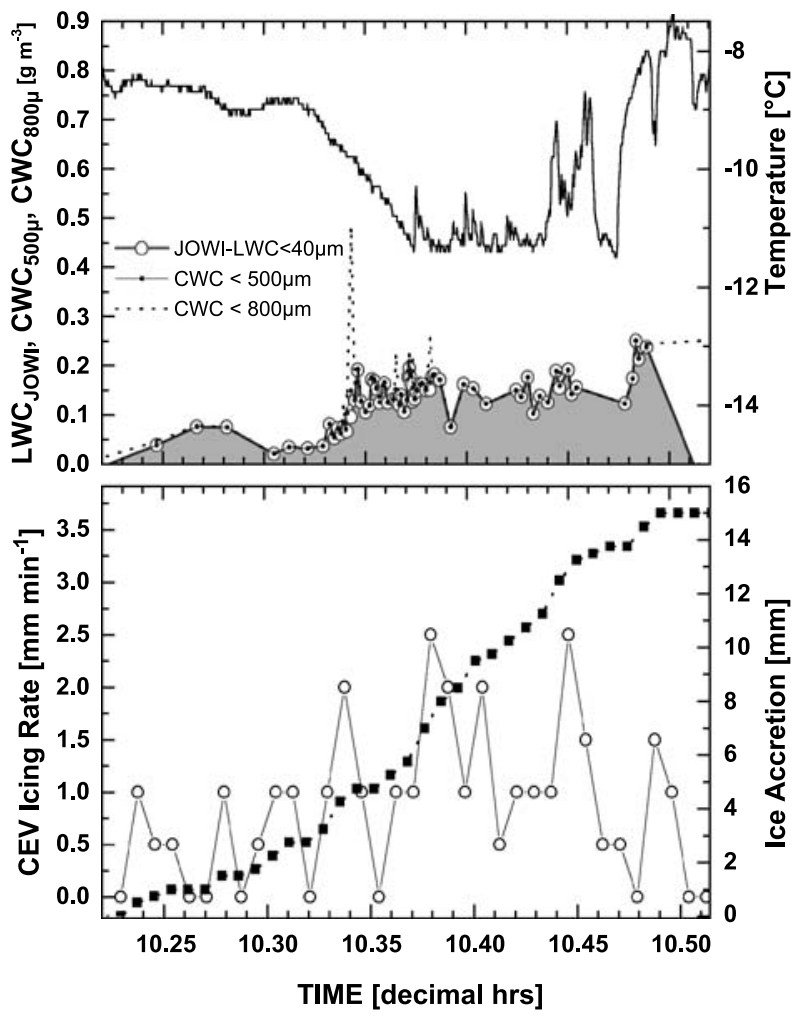

Fig. 9. As in Fig. 8, but for flight sequence Seq2 (10:2010:28) on March 15. The average JoWi-LWC during 10.3510.50 decimal hrs is about $0.15 \mathrm{~g} \mathrm{~m}^{-3}$ which is $30-40 \%$ less compared to Seq1. Significant ice accretion was observed only at the leading edge and on the boot protected regions below the wing (not shown)

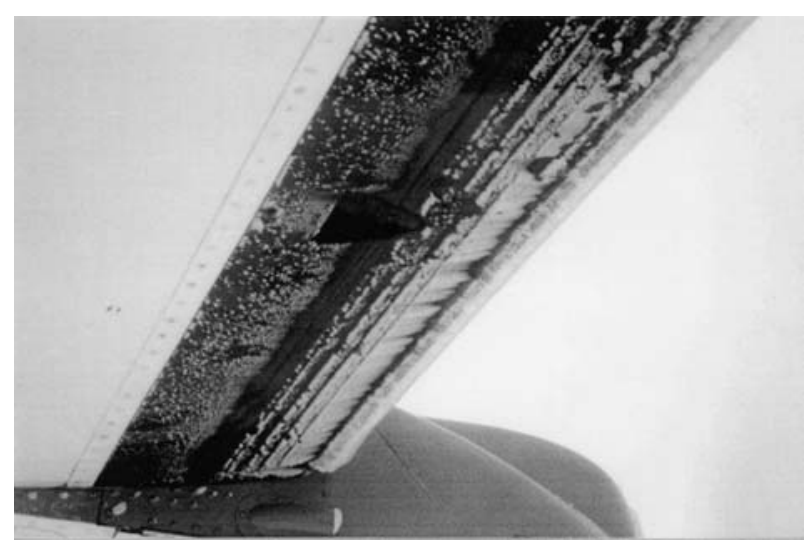

Fig. 10. Ice accretion shortly after Seq1 on the wing underside, from the leading edge to behind the boot-protected region below the wing, between cabin and the turboprop engine (left). The boot protected region ends within the dark lined area along the wing span. The leading edge carries at least a $10 \mathrm{~mm}$ thick, partly clear, ice cover. The boots were not activated yet. Ice streaks immediately behind the leading edge indicate back-running. Further downstream and at least $30 \mathrm{~cm}$ behind the protected area patchy ice fragments are observed 
within the time interval of Seq1, lasting 1-3 sec where the OAP instruments gave significant counts in the SLD range. Altogether the 10 flight segments comprise $\sim 10 \%$ of the Seq1 time interval of 4 minutes and do represent the 10 strongest peak events.

To contrast the two flight segments Seq1 and Seq2, a reference segment Seq3 (10:13-10:18) was chosen at a flight level of $3060 \mathrm{~m}$. Seq3 has only an insignificant large-particle-mode, significantly less SLD than both Seq1 and Seq2 and also less liquid water in the cloud drop mode (cf. Fig. 13). The ten $\mathrm{LWC}_{\text {JoWi }}$ peak segment values are close to the average value for the whole Seq1 of $0.25 \mathrm{~g} \mathrm{~m}^{-3}$ and do not exhibit much scatter (not shown). The average peak value is $0.26 \mathrm{~g} \mathrm{~m}^{-3}$ while for Seq2 we find with $0.15 \mathrm{~g} \mathrm{~m}^{-3}$ less and for the reference sequence Seq3 with $0.09 \mathrm{~g} \mathrm{~m}^{-3}$ significantly less liquid water. The little scatter in the Johnson-Williams data is due to the low sensitivity for drop sizes larger $30 \mu \mathrm{m}$ (Biter et al, 1987), and the little variability of the cloud drop mode which will be shown in the spectra (Fig. 11).

We have tested how sensitive the mean volume diameter (MVD) calculation is to the inclusion of larger particles and found that the average MVD for Seq1 is shifted from a value somewhere between 20 and $30 \mu \mathrm{m}$ to the range 50 to $70 \mu \mathrm{m}$ if only the ten peak events within Seq1 are considered. Thus during the peak events we have only a slightly increased cloud drop liquid water content but clearly enhanced MVD values.

Using the size distributions discussed below, we determined the number concentrations in various intervals and found that the majority of the particles in the SLD size range $<500 \mu \mathrm{m}$ resides in the range up to $150 \mu \mathrm{m}$. This is confirmed by the OAP shots (Fig. 12) where visually identified drops have diameters smaller $200 \mu \mathrm{m}$. There is more than a factor 10 less SLD in Seq2 as compared with Seq1 but still a factor 10 more than in the reference segment Seq3. The MVD values, therefore, tend to be shifted to smaller values from Seq1 to Seq2 and to Seq3. These findings emphasize the occurrence of increased liquid water content in the cloud drop mode and the existence of SLD $<150 \mu \mathrm{m}$ on short spatial scales.

\subsection{Detailed study of spectra of SLD-event Seq1}

Number and volume spectra of the cloud particles during Seq1 were calculated for the ten flight segments and plotted together in Fig. 11. The cloud particle number distribution is shown in the left panel and the volume distribution in the right one. Both were calculated from FSSP100ER and OAP data for Seq1 (bold line and open symbols) and also for ten peak events (thin

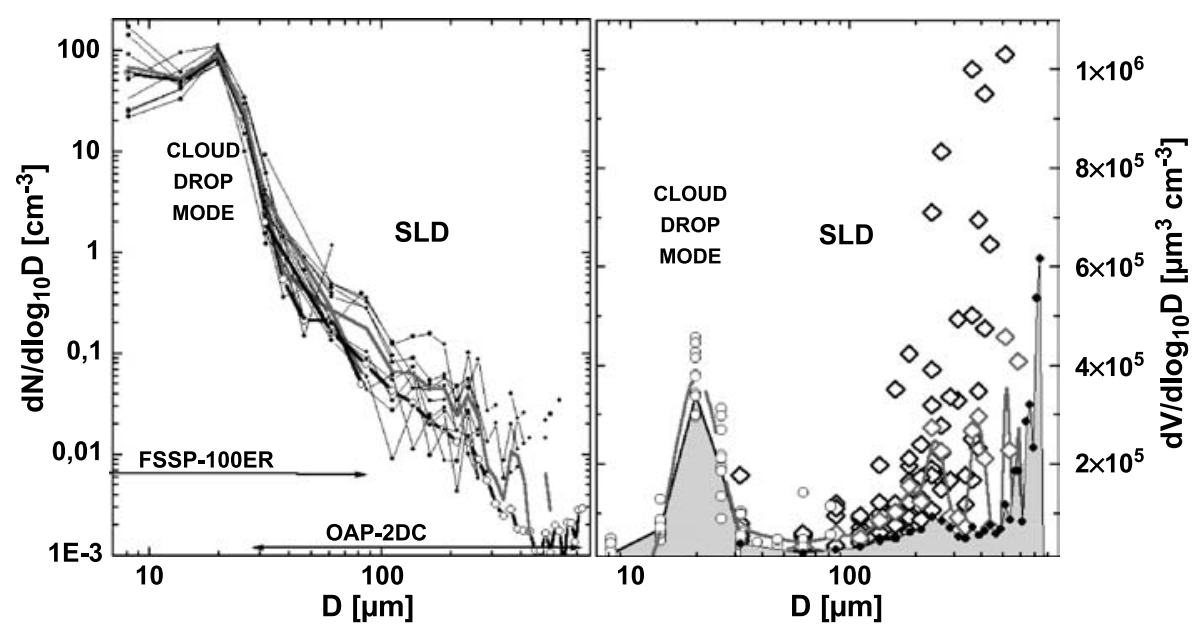

Fig. 11. Composite cloud particle number spectral distribution (left panel) and volume distribution determined from the FSSP-100 and OAP for Seq1 on March 15th (bold line and open symbols) and for ten peak events (thin lines with dots). Left panel: Spectra are plotted separately for both FSSP and OAP in the overlap size range 30-95 $\mu \mathrm{m}$. The average of the peak event spectra is displayed as a grey solid line without symbols. No continuous line in case of too few particles within the sampling time of 1-3 s. Right plate: Spectrum for Seq1 is highlighted by grey shading beneath. Ten peak segments with large not-connected symbols, average spectrum grey solid line 


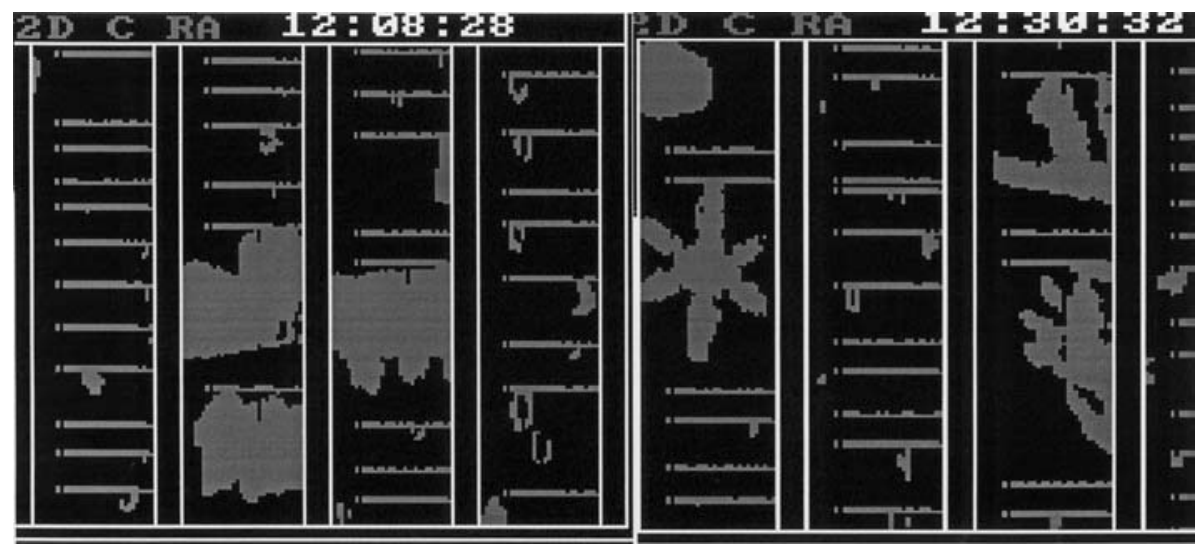

Fig. 12. OAP-2DC images of cloud particles from March 24, taken near cloud top (right plate, 12:30 UTC, leg D in Fig. 14) and at $2200 \mathrm{~m}$ (left plate, 12:08 UTC, leg B in Fig. 14). Horizontal width of each of the three stripes corresponds to $0.8 \mathrm{~mm}$ in particle size, the vertical scale is the same. Bright horizontal bars are separators for individual images

lines with dots) with their respective average (grey solid line without symbols). Please note that spectra are plotted separately for both FSSP and OAP in the overlap size range $30-95 \mu \mathrm{m}$. Differences between both instruments are an immanent feature due to specific differences in the error characteristics. These differences, therefore, indicate the general uncertainty in particle numbers - an inherent feature in particle sizing. Also it should be kept in mind that the detection of particles for size ranges over $300 \mu \mathrm{m}$ is affected by low numbers and, therefore, has a poor statistics, with related scatter in the calculated distributions. The right plate shows the volume distribution in a logarithmic-linear representation where the areas under the respective curves give exactly the total volume in that size range. The left plate gives the number distribution in a $\log -\log$ presentation.

The volume distribution shows quite clearly the three discussed modes, the cloud drop mode, the SLD mode and the large-particle mode. For better illustration the area under the Seq1 curve is shaded. The ten peak segments are displayed with only large not-connected symbols to demonstrate the large scatter due to large individual particles and their contribution to the total Seq1 spectrum. The average over the peak events (grey curve) is always above the Seq1 curve. Thus, during $10 \%$ of flight time of Seq1 most of the water is concentrated in short peak events and, therefore, much less in between. When discussing the large-particle mode it has to be noted that no algorithm with an automatic discrimination between liquid and solid particles was applied to the data. The partition of total particle volume into liquid and solid is, therefore, not determined. From the OAP screen shots (cf. Fig. 12) we know that there were always during the flight mixed phase conditions but we did not find liquid drops larger $500 \mu \mathrm{m}$. We, therefore, conclude that larger particles did not contribute to aircraft icing. This does not hold for particles smaller $500 \mu \mathrm{m}$. Here we have unambiguously identified a mixture of both liquid and solid particles.

Turning now to the number distribution (left plate of Fig. 11), we find a well expressed cloud drop mode with one and only one maximum at $20 \mu \mathrm{m}$. The SLD mode is at least 3 orders of magnitude lower than the cloud drop mode, and is only recognizable as a small hump in the declining part of the number spectrum at about $150 \mu \mathrm{m}$. Comparing the Seq1 spectrum with the segment spectra containing the individual bursts, we see that they differ significantly for the SLD mode with short term spectra having up to a factor ten more particles. The SLD mode is, therefore, mainly concentrated in the peaks recognizable in the time series of liquid water content (Fig. 8). This is also confirmed when the video sequences of the ice accretion on the icing cylinder is viewed, as the impact of SLD can be identified there. The detection of SLD by eye is not only possible on a deiced and clean cylinder as in Fig. 3, left panel, but also when ice has accreted already. From the volume distribution (right plate of Fig. 11) we concluded that the SLD mode of the short term spectra may contain more liquid water than the cloud drop mode. On the average for Seq1, however, the cloud drop 
mode is dominant in both number and volume spectrum. The third, large particles mode is negligible in number. The previously discussed low scatter of $\mathrm{LWC}_{\mathrm{JoWi}}$ values is also reflected in Fig. 11, where the curves in the cloud drop mode coincide more or less.

\subsection{Detailed study of SLD-event Seq2}

Having focused mostly on Seq1 we turn now to Seq2. Figure 9 illustrates that during Seq2, at a temperature of $-11^{\circ} \mathrm{C}$, no bursts as in Seq1 were observed. All three quantities $\mathrm{LWC}_{\mathrm{JoWi}}, \mathrm{CWC}_{500}$ and $\mathrm{CWC}_{800}$ coincide nearly completely, pointing towards an absence of larger particles, e.g., ice particles. Figure 13 shows in a similar fashion as Fig. 11 the number and volume distribution for Seq2 (triangles) and additionally for better comparison Seq1 (circles), Seq3 (squares), and for the one peak segment within Seq1 at 9:55:47-9:55:48 (dots). The volume distribution is shown in a $\log -\log$ representation, in contrast to Fig. 11 where a lin-log one was preferred. Seq2 was at $-11^{\circ} \mathrm{C}$, thus nearly two degrees colder than Seq1, and the LWC was $0.15 \mathrm{~g} \mathrm{~m}^{-3}$ and slightly lower than the $0.25 \mathrm{~g} \mathrm{~m}^{-3}$ value of Seq1. It should be noted that the segments were flown in different clouds having different cloud bases and vertical extents. The cloud with Seq1 ranged from $2700 \mathrm{~m}$ (base) to $3050 \mathrm{~m}$ (top) with Seq1 at $3040 \mathrm{~m}$ close to cloud top while the cloud with
Seq2 ranged from 3050-3350 m. Despite their difference in altitude, both Seq2 and Seq 3 where flown close to cloud top of the respective clouds. One should note that both sequences feature high icing rates with $\sim 3.5 \mathrm{~mm} / \mathrm{min}$ in Seq1 and 1$2.5 \mathrm{~mm} / \mathrm{min}$ in Seq2, while the reference segment Seq3 had 0-0.5 mm/min (cf. Figs. 7 and 8).

Figure 13 shows that Seq2 differs substantially in both number concentration as well as volume distribution in the SLD mode, with Seq1 by one order of magnitude, and even more with the one peak segment of Seq1 (dots). All three segments, however, approach equal levels in both the cloud drop mode and the large-particle mode. The latter fact is easily explained by the sufficiently discussed presence of large ice particles. The equality of the cloud drop spectra for Seq1 and Seq2 explains the nearly similar icing rates, which again is in line with the arguments that icing is mainly caused by the cloud drops. Seq3 has the same maximum value within the cloud drop mode, but the right-hand flank declines significantly earlier than for both Seq2 and Seq3. Thus the LWC is significantly lower for Seq3 as well as the icing rate (cf. 10:13-10:18 in Fig. 7). The occurrence of SLD seems to be correlated with the LWC in the cloud drop mode. The difference in SLD number as well as volume content for Seq1 and Seq2, however, cannot be related to such differences as spectra coincide till $30 \mu \mathrm{m}$. The $\mathrm{LWC}_{\text {JoWi }}$ differences between Seq1

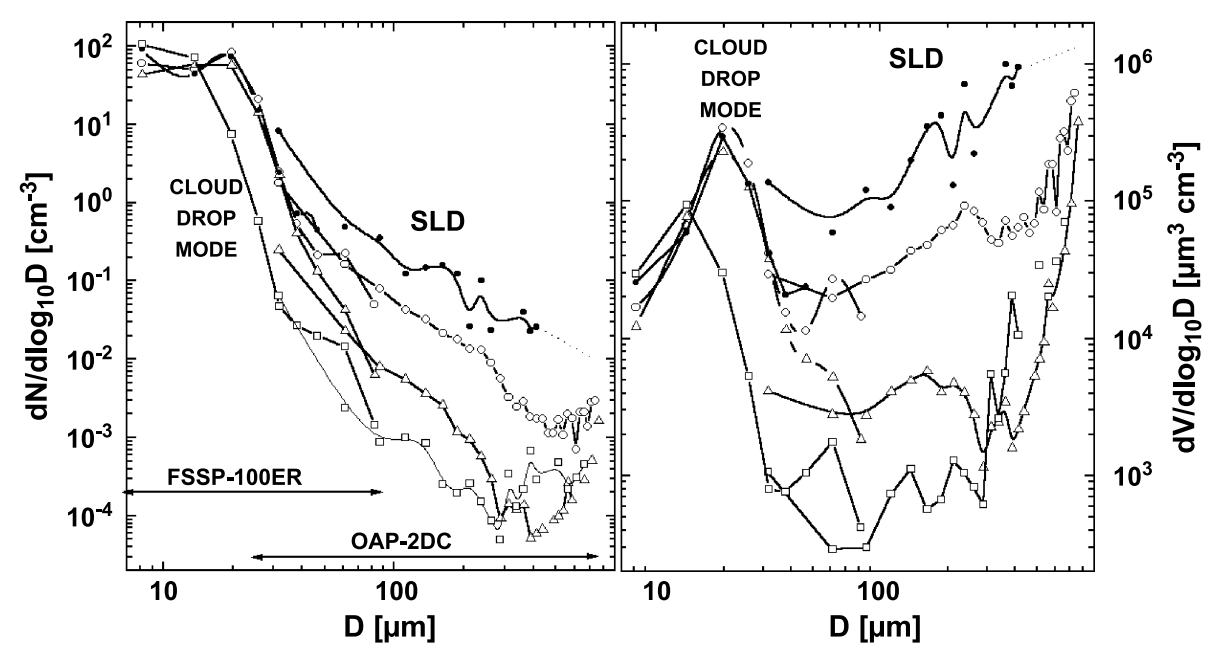

Fig. 13. Composite cloud particle spectral number distribution (left panel; log-log presentation) and volume distribution (right plate; log-log presentation) determined from the FSSP-100ER and OAP for Seq2 (triangles), Seq3 (squares), for better comparison also for Seq1 (circles), and for the one peak segment within Seq1 (9:55:47-9:55:48 UTC, dots) on March 15. Please note that the volume distribution is shown in a log-log representation, in contrast to Fig. 11 where a lin-log one was preferred 
and Seq2 can only be explained by the lower values of number spectra larger $30 \mu \mathrm{m}$, despite the declining sensitivity of the JoWi instrument in that size range. In conclusion, Seq1 stands for relatively high icing rates, high $\mathrm{LWC}_{\mathrm{JoWi}}$ and high SLD values, while Seq2 has also high, but slightly lower icing rates, slightly less $\mathrm{LWC}_{\mathrm{JoWi}}$ and lower but still detectable SLD values. The single peak segment (dots) exhibit almost four orders of magnitude more SLD than in the reference segment Seq3. Please note that for the single peak segment the existence of particles larger than $400 \mu \mathrm{m}$ is omitted due to poor statistics. In summary, in the mixed phase embedded convective clouds well expressed SLD cloud volumes exist on spatial scales of 100 to $200 \mathrm{~m}$ with ten times more SLD than compared with the average over the whole traverse through the cell. This large variability within a cell represents a major finding of this study.

\subsection{The nature of the particles}

The question arises what cloud particles contribute to the three modes defined above and observed in Seq1 and also Seq2. So far we have assumed that particles in the SLD mode are predominantly liquid. This, however, has to be supported by arguments (see Section 3.7). Eye inspection of the OAP-2DC images for Seq1 (not shown, cf. Fig. 12) reveal that no liquid drops larger than $\sim 300 \mu \mathrm{m}$ were present but only ice particles of various shape. Thus particles larger than that value can definitely be considered as ice particles. On the other side of the size spectrum the cloud drop mode centered at about $20 \mu \mathrm{m}$ is caused by predominantly liquid drops. The existence of small ice crystals cannot be excluded, though there were no indications for that. The question remains about the phase of the intermediate sized particles, respectively whether there are supercooled large particles (SLD) present. There are three strong arguments supporting the existence of SLD. The first emerges from an interpretation of the OAP-2DC images where liquid particles in the size range $<300 \mu \mathrm{m}$ can be identified (see Fig. 12). The topic of misinterpretation of spherical particles is discussed further below in section 3.7. Second, SLD can also be identified on video, but frequently also by eye, with a short white flash during the time of impact when they change phase. They can be observed on the icing cylinder (see Fig. 3, left plate), on the leading edge and on the underside of the wing (see Fig. 10). Figure 10 also shows that particles impacted behind the protected parts of the wing and froze there. The impact in that area is only known for liquid particles larger than $\sim 50 \mu \mathrm{m}$, especially for SLD (Politovich, 1996). We, therefore, conclude that the SLD-mode in Seq1 is due to liquid and supercooled drops. Studying the bimodal structure of the spectra (Fig. 11) from Seq1 with the cloud drop and the SLD mode in more detail, calculations were performed over various size ranges to determine the total water content, respectively the liquid water content in that range. Quite surprisingly it was found that the SLD mode, on the average, constitutes not more than about $20 \%$ of the total supercooled LWC where integration was performed up to cloud-particle diameters of about $500 \mu \mathrm{m}$. This value might be even lower as the integration limit of $500 \mu \mathrm{m}$ will certainly include some ice particles. Even the average median-volume diameter (MVD) of the complete Seq 1 with a length of $\sim 20 \mathrm{~km}$ stays well below $40 \mu \mathrm{m}$ and is, therefore, covered by the FAR/JAR Appendix C framework. MVD-values may be larger than $50 \mu \mathrm{m}$ for peak events, but for short time periods only, and shorter than required by Appendix C. Icing conditions of this study are consistent with those of Appendix C.

\subsection{The icing flight on March 24, 1997}

The flight mission of March 24 allowed a more systematic cloud sampling as compared with March, 15. The weather situation was very similar with a stratiform cloud field having cloud base and top at approximately 1800 and $3200 \mathrm{~m}$, respectively. The flight track consisted of 6 parallel and vertically staggered legs. The legs were oriented in a NNW-SSE direction (see Fig. 6). The various flight legs were flown along that direction at five different altitudes labeled A-E in Fig. 14.

The DLR weather-radar was active on that day and provided continuously horizontal radar reflectivity scans. A detailed analysis of the flight track and the radar images was made by Stingl (1999). Figure 6 shows a radar image from March 24 with the convective cells cloud field and the corresponding flight track superimposed. Quite surprisingly, the radar revealed individual 


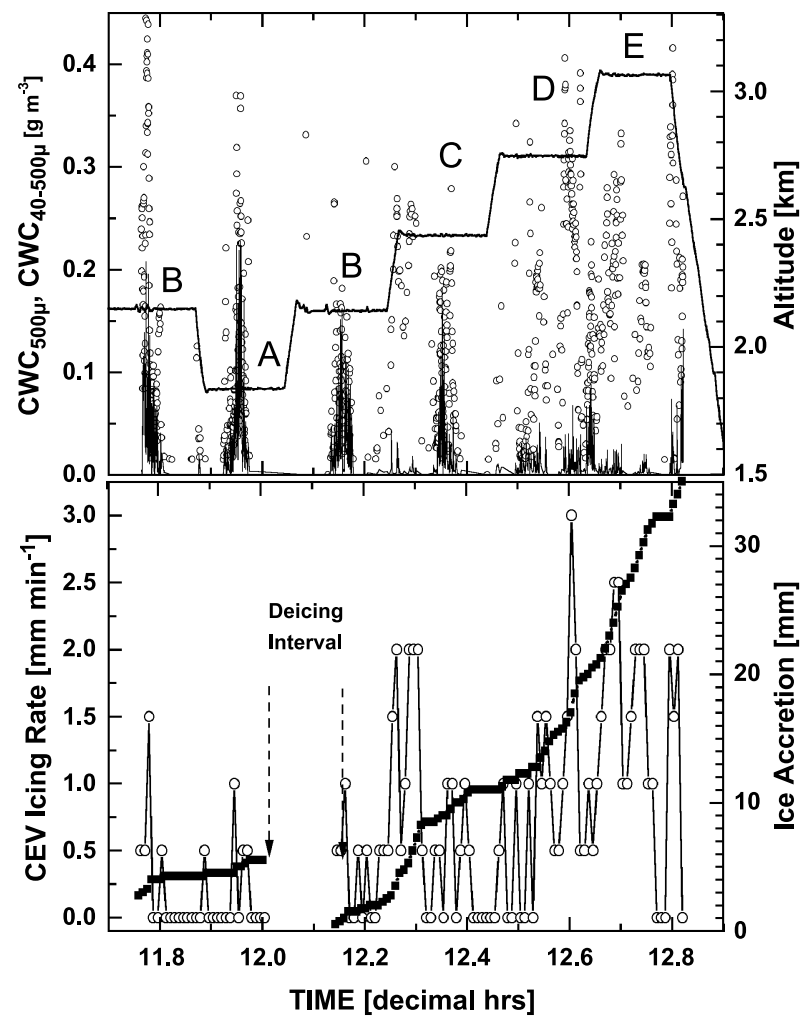

Fig. 14. Icing parameters obtained during one hour cloud sampling on five different altitude levels, A-E, on March 24 (cf. flight pattern Fig. 6). Upper panel: Integral CWC ( $<500 \mu \mathrm{m}$, circles), CWC $>40 \mu \mathrm{m}$ (OAP-derived, thin line) and pressure altitude (bold step line, right scale). Lower panel: ice accretion onto the icing cylinder and icing rate (compare Figs. 8 and 9). The integrated ice accretion exceeds $30 \mathrm{~mm}$ and the de-icing boots were activated twice during the entire period 11.7-12.9 decimal hrs

clouds with spatial scales of several kilometers, rather than the visually apparent extensive stratus cloud as were seen by the aircraft. Having in mind that a C-band radar is sensitive only to particles much larger than $100 \mu \mathrm{m}$ and thus does not detect the normal cloud drops centered around $20 \mu \mathrm{m}$ which were found on March 15 in the stratus cloud, it was concluded that the cloud field consisted of a stratus cloud with embedded convective cells. This is supported by the photograph (Fig. 4) of the upper cloud deck where an overshooting top of such an embedded convective cell is recognizable. This explains also the above mentioned periods of vigorous turbulence noted during the flights. Comparing the time of the passages through the convective cells with the occurrence of significant icing rates and increases in cloud particle number densities, Stingl (1999) found unambiguous evidence that the icing events occurred when the aircraft traversed a convective cell. The horizontal scale of such a convective cell is on the order of several kilometers. As the aircraft does not always pass through the center of the cell, aircraft traverses can be shorter, leading to the range of observed icing event durations. With a true airspeed of $80 \mathrm{~m} \mathrm{~s}^{-1}$, the time spans of the aircraft's exposure to icing ranged between 6 and 60 seconds. Again as on March 15, SLD were observed together with high icing rates during the traverse of a convective cell (Fig. 14). No SLD were observed outside a convective cell.

Stingl (1999) further found that the convective clouds moved with the mean wind across the flight path in a south-easterly direction, and, simultaneously grew in size, and later also merged with each other (not shown). As this all happened during the flight, it became clear by the analysis that the data from the various flight levels originate from different clouds, from different sections within one cloud and from different life stages of the respective clouds. We, therefore, cannot consider data from one level and data from another level as snapshots of the same one cloud at one instant of time. We rather have to compare them in a statistical sense.

Figure 14 shows in the upper plate the height time series together with the cloud water contents $\mathrm{CWC}_{500}$ and $\mathrm{CWC}_{800}$. During the traverses of convective cells very clearly peaks appear in both quantities at all levels. These traverses are accompanied by peaks in the ice accretion rate with a maximum value of $3 \mathrm{~mm} \mathrm{~min}^{-1}$. It should be noted that the ice accretion rate is increasing from level to level. After the aircraft had ice accreted almost $40 \mathrm{~mm}$ on the icing cylinder during the flight and its deicing boots had been activated twice, it was for safety reason forced to exit the upper cloud region at about 12:48 UTC and made a descent. By that time the engine-thrust level had to be increased from about $45 \%$ to about $80 \%$ to maintain a true airspeed of $80 \mathrm{~m} \mathrm{~s}^{-1}$. The measurements on March 24 confirm the findings of March 15 that icing occurs in short bursts which now can unambiguously be attributed to the passage of convective cells embedded in the stratus cloud.

Now we focus on mean vertical profiles. For each level A-E at least several minutes of cloud penetration have been evaluated and the mean 
values, the $25 \%-, 75 \%$-, and $90 \%$-percentiles of liquid water content (JoWi), cylinder icing rate and the cloud water content derived from OAP data for particles larger $42 \mu \mathrm{m}$ were determined. These mean profiles of Fig. 15 very clearly show, that both the liquid water content and the icing rate increase with height, while the cloud water content CWC decreases. We also observe that the scatter of both liquid water content and icing rate increase with height while the one of CWC decreases. As the liquid water content was measured with the Johnson Williams instrument, which is only sensitive to drops smaller $40 \mu \mathrm{m}$ (Vali, 1997; see also Biter et al, 1987), the observed liquid water content and its increase with height must be caused by cloud drops. This finding is in line with the well-known and common structure of a convective cloud. The liquid water content amounts to approximately $10-20 \%$ of the adiabatic liquid water content. There is no change of mean liquid water content between the two uppermost levels D and E. This is very likely caused by entrainment from the cloud top as the flight level $\mathrm{E}$ was just $100 \mathrm{~m}$ beneath the cloud top. As the cloud did not show a sharp edge, rather a fluctuating transition zone, parts of the flight path could even be closer to the dry atmosphere aloft, thus reducing the liquid water content. The scatter of the LWC values increases also with height up to level D. This is due to the fact that at the upper levels, except the uppermost one E, the maximum liquid water content increases within the convective cells while outside stratus values are lower and furthermore do remain constant at one level. Thus the horizontal average must show an increasing scatter with height. As the liquid water content increases with height, ice accretion increases with height as well. This correlation was already found on March 15. The decreasing cloud water content with height for particles larger $42 \mu \mathrm{m}$ can simply be explained by ice particles growing in size and increasing in number while falling. Thus the lower panel c reflects the falling motion with the cloud, while panel $b$ indicates the upward motion of cloud drops.

Do the spectra confirm this view? Figure 16 shows on the left panel the number spectra and on the right panel the corresponding volume spectra. Spectra were calculated for various sampling time intervals and compared with the Seq1 spectrum from March 15 (solid line with circles).
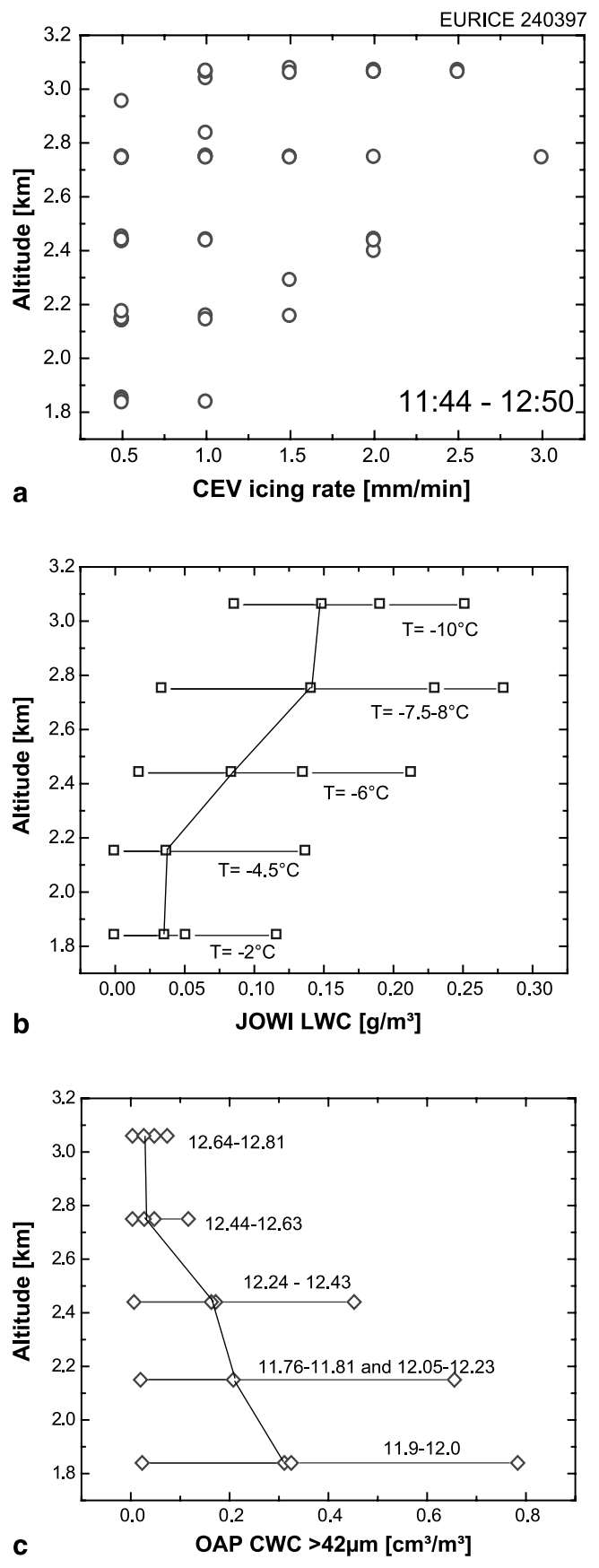

Fig. 15. Mean cloud profiles for March 24. Upper panel (a): cylinder icing rates (30 s averages). Middle panel (b): liquid water content (JoWi) with 25-, 75-, and 90\% percentiles during the sequences A-E. Mean level temperatures are indicated. Lower panel (c): cloud water content derived from OAP-2DC data (diameter $>42 \mu \mathrm{m}$ ) with 25-, 75-, and $90 \%$ percentiles. Time intervals are indicated. Note that $\mathrm{CWC}$ is given in units of $\mathrm{cm}^{3} \mathrm{~m}^{-3}$

Dotted spectra refer to flight levels A and B, while dashed spectra refer to flight level D. Unfortunately, FSSP data are missing due to instrument 


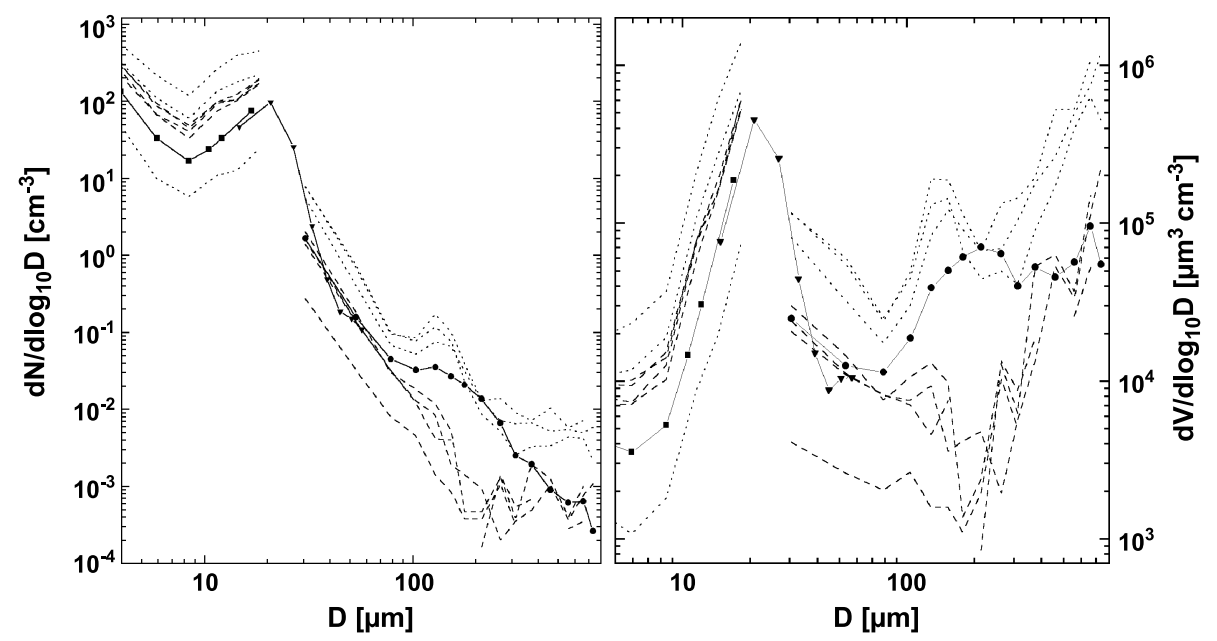

Fig. 16. Composite cloud spectral number distribution (left panel) based on FSSP-300 and OAP-2DC data, but due to failure not with FSSP-100ER, and specific volume distribution (right panel) acquired over typically 6-20 s cloud sampling intervals on March 24. Dotted spectra were sampled between 11.65-12.15 decimal hrs on flight levels A and B near cloud base and dashed spectra between 12.5-12.6 decimal hrs on flight level D in the upper cloud part and close to cloud top. For comparison reasons Seq1 spectra are included (cf. Fig. 11) as solid lines with symbols (squares FSSP-300, triangles FSSP-100ER, circles OAP-2DC)

failure causing a gap in the spectra in the cloud drop mode. The overall picture is the same as on March 15: (i) a cloud drop mode at about $15 \mu \mathrm{m}$, (ii) the SLD mode at about $150 \mu \mathrm{m}$, appearing as a hump in the declining part of the spectrum, and (iii) the large particle mode for diameters larger $300 \mu \mathrm{m}$. There is only little scatter in the cloud drop mode for the various segments, in contrast to the SLD-mode where a considerable scatter by a factor of $\sim 8$ exists. Caused by the high variability in large ice particle concentration, we found again as for the March 15 flight a large scatter in the large particle volume distribution. Due to the instrumental failure, no conclusions can be drawn for the vertical profile of the spectra within the cloud drop size range.

Figure 17 was taken before the final descent and after deicing. It shows that ice also accreted on parts of the wing which were not protected by the pneumatic boots. The latter also failed to remove the ice close to the fuselage (upper right) and left a ridge near the leading edge. In summary, the flight on March 24 confirmed the results found during the previous flight on March 15, but, with the help of the radar measurements, additionally related the peaks and bursts in liquid water content and ice accretion to embedded convective cells. Further results will be discussed below.

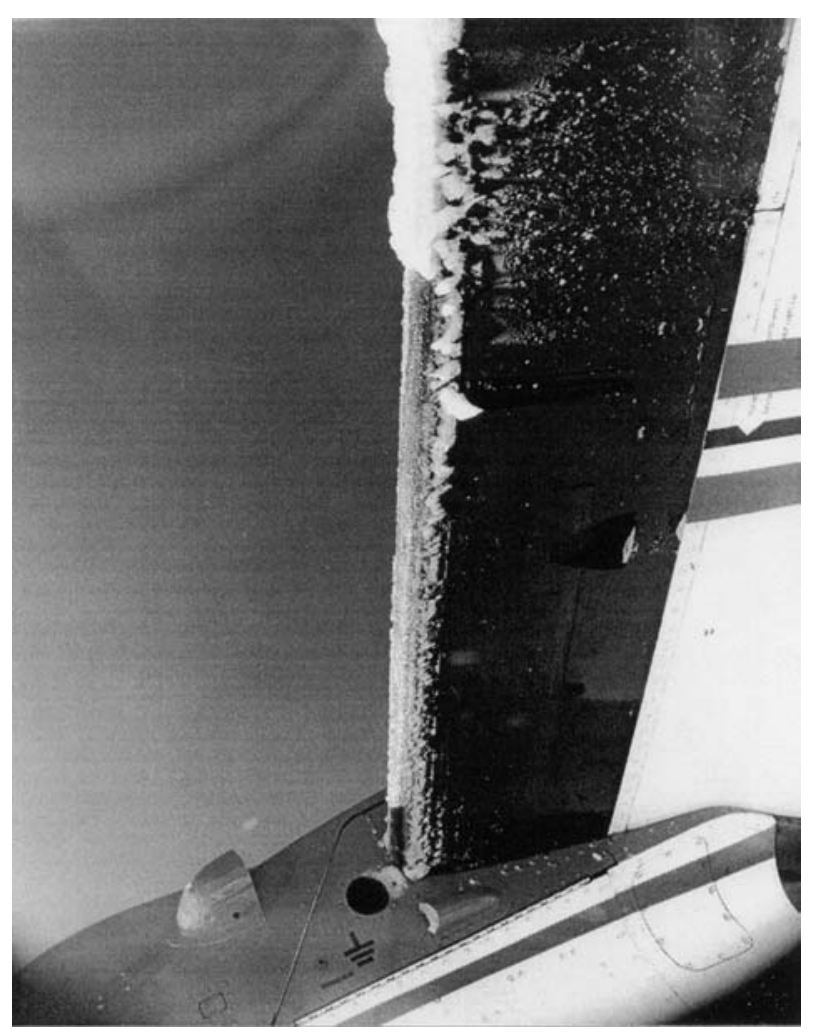

Fig. 17. View from below on the section of the wing between engine (left) and fuselage (right) on March 24 taken after deicing at about $3000 \mathrm{~m}$ and shortly before final descent. Note that parts of the accreted ice could not be removed by the pneumatic boots 


\subsection{Cloud-particle types}

In-cloud-particle images taken with the OAP cloud probe (Fig. 12) are shown for two flight segments. The right plate of Fig. 12 was taken at $2700 \mathrm{~m}$ near cloud top, the left plate at $2200 \mathrm{~m}$ MSL in the lower part of the cloud. The horizontal width of one image is $775 \mu \mathrm{m}$. Horizontal lines represent trigger pulses. The "zero-images" in both panels are indicative for numerous triggering events in the lowest OAP-channel $(\sim 20-$ $42 \mu \mathrm{m}$ particle diameter). The diffraction pattern in the center of a circular shaped image, the Poisson spot, is a necessary but not sufficient condition for the particle being a spherical drop. There is still some ongoing discussion about problems using the Poisson spot as a criterion for identifying the liquid state of a particle (Korolev et al, 1998). In the given case, however, we have evidence for the existence of liquid drops through the video documentation of impacting drops, and the impact and secondary growth of frozen drops on the wing underside. Some of the spherical shaped particles may also be frozen. The images reveal individual ice crystals (hexagonal structure), graupel, needles, and spherical images of particles. All very large ice particles $(>1 \mathrm{~mm})$ seem to be rimed and most likely do not contribute to ice accretion on the airplane. We conclude that both ice particles and supercooled, liquid drops, respectively, SLD existed in the cloud. The size of the liquid drops is approximately 200 to $300 \mu \mathrm{m}$ maximum, while partially imaged solid particles may exceed $1 \mathrm{~mm}$ in size. Liquid particles, therefore, seem to have been limited in growth. Please note that the slight elliptical deformation of the drop image is due to a not properly set true air speed in the imaging software. In the lower part of the cloud, the ice particles are more heavily rimed with a less pronounced though still recognizable crystal structure, and they contribute more to the observed cloud water content. This is in line with the common picture of precipitation formation in a convective cloud. In summary, the investigated convective cells contain both liquid and solid particles at all levels. While the cloud drop liquid water content increases with height, the opposite is true for the cloud water content for particles larger $42 \mu \mathrm{m}$. The size of SLD seems to be constant with height while their liquid water content shows considerable scatter, but do insignificantly contribute to the total water content, respectively, to the accreted ice.

\subsection{The further icing flights}

Icing was observed on three more flights (see Table 1: no. 4, March 19; no. 6, March 25; no. 7, March 26). On March 19, embedded convection prevailed and moderate icing was experienced. SLD were identified on the video. The weather situation was similar to March 24 with slight rain observed at the ground. Aircraft data, however, was not available. On March 25, icing was found under mixed phase conditions. Unfortunately, radar data were missing on that day. On March 26, light to moderate icing was observed within cumulus and stratocumulus clouds again under mixed phase conditions. In-cloud temperatures ranged between $0^{\circ}$ and $-5^{\circ} \mathrm{C}$. All these flights confirm the importance of embedded convection with mixed phase clouds for aircraft icing, though the ice accretion rates were not as high as on March 15 and/or March 24. Because of the aforementioned and some other limitations, a deeper evaluation of this data was not performed.

\section{Conclusions}

This papers documents icing research flights which were performed in March 1997 in the pre-Alpine area near Munich, Germany under the conditions of embedded convection. Two cases with significant aircraft icing were discussed in detail. In this section, we discuss and summarize the main findings.

\subsection{Embedded convection and patchiness of aircraft icing}

The two cases discussed in this paper and also the other flights with subzero temperatures had similar weather conditions with an extended stratus cloud with embedded convective cells. The cloud regime was found in the lower troposphere with cloud tops at about $\sim 3500 \mathrm{~m}$. Individual convective clouds overshot the stratus cloud deck by approximately two hundred meters and could be visually identified from above. To the authors' knowledge, embedded convection so far was not considered as especially relevant for aircraft 
icing, in contrast to our results of substantial icing with a maximum icing rate of $3.5 \mathrm{~mm} / \mathrm{min}$ min in the convective cells but only marginal accretion rates in the surrounding stratus. The length of an in-cloud passage with notable ice accretion ranged in the reported cases between several hundred of meters and several kilometers and is determined by the random flight track segment length through the cell. This patchiness of aircraft icing was already observed in North American East Coast storms (Cober et al, 1995).

Repeated traverses as they, e.g. may occur during holding patterns may result in an increasing amount of accreted ice. Such a scenario led to the Roselawn accident (Sand et al, 2000), though we do not claim that embedded convection prevailed during the time of that accident and did cause it. The hazard of embedded convection is enhanced by the fact that the pilot, while flying within the stratus cloud, does not recognize the embedded convective cells by eye.

\subsection{Mixed phase conditions}

The flights also emphasize the importance of mixed phase conditions for aircraft icing. A check of OAP images reveals the existence of drops in all investigated clouds and at all flight levels. Together with the cloud drop spectrometer measurements we infer that liquid water was present, in both the cloud mode and the SLD mode, through the whole depth of all cells. Our findings confirm the relevance of coexisting phases for aircraft icing which has been documented in a series of fine papers by Cober and his colleagues on research flights during the Canadian Atlantic Storms Program (Cober et al, 1995; 1996a; 1996b) and the Canadian Freezing Drizzle Experiments (Cober et al, 2001a; 2001b). Cober et al (2001b) also worked out the technical problems in assessing cloud-phase conditions, especially in mixed phase clouds and using common cloud particle sizing instrumentation. Despite of the documented importance of mixed phase conditions for aircraft icing, it has not been much investigated yet (Riley, 1998), though the icing handbook (FAA, 1991) considers mixed phase conditions as very critical from an icing standpoint. Mixed phase conditions are thought to be unstable, seldom and rapidly changing with time. The reasoning behind is that the natural glaciation of the cloud proceeds very rapidly once ice crystals have formed, leading to a complete depletion of liquid water. This is contrasted by the always found mixed-phase conditions in the EURICE flights, and the $26 \%$ and $46 \%$ occurrence during the first and third Canadian Freezing Drizzle Experiments (Cober et al, 2001b). Though ice particles grew by riming, there was still sufficient supercooled liquid water in the cloud drop mode to cause the observed ice accretion. Although the temperature range $[-5$, $-10{ }^{\circ} \mathrm{C}$ ] was suitable for the Hallet-Mossop process of ice multiplication (Hallet and Mossop, 1974), there was no indication found for that process. Two possible explanations for the absence of complete glaciation can be given. First, the relatively warm temperatures $>-11^{\circ} \mathrm{C}$ do not support the activation of a sufficient number of ice nuclei. Second, vertical advection of humid air and subsequent condensation may lead to continuous and substantially new formation of liquid water. Vertical wind speed was not measured but may be guessed to be on the order of $5 \mathrm{~m} \mathrm{~s}^{-1}$, as it is typical for continental spring time shower clouds. Following the arguments by Rauber and Tokay (1991), a possible reason for the observed mixed phase conditions is that more liquid water is produced by the combined action of vertical advection and condensation than is depleted by glaciation. Rauber and Tokay focused on the uppermost layer of a cloud. This is also the region were we found the maximum of liquid water content of the cloud drop mode (cf. Fig. 15, panel b), respectively, measured with the Johnson Williams instrument. Following the arguments by Rauber and Tokay, we conclude that the observed drizzle drops must have formed via the coalescence process, very likely in the upper cloud layers, and then settled down to lower levels. Our conclusion is furthermore supported by the fact that the convective cells were embedded in a stratus cloud. Without this humid and cloudy environment, entrainment of ambient air would reduce the liquid water content in the main updraft, even more than in our case where an already low value of $10 \%$ of the adiabatic was found. One should note that the flight paths did not necessarily lead through the center of the cells. Thus the low value of $10 \%$ results already from entrainment of ambient stratus air with lower LWC values but still saturated air. 
The hypothesized reduced mixing effect, though theoretically obvious, might, therefore, probably be small. Results are in agreement with the present picture of cloud-particle spectra in mixedphase clouds (see, e.g., Strapp et al (1996), and Hobbs and Rangno, 1985) dividing the spectrum into a cloud drop mode centered at about 15$20 \mu \mathrm{m}$ and an ice particle mode related to graupel and other ice crystals larger $200 \mu \mathrm{m}$. Both modes are separated by a gap at $\sim 100 \mu \mathrm{m}$, the level of which varies according to the existence of a third mode with drizzle drops, respectively SLD. In the volume spectra these drops can be identified by an additional relative maximum within the gap, respectively, in the number spectrum as a slight hump in the declining flank of the cloud drop mode (see Figs. 11, 13 and 16).

\subsection{Existence of supercooled large drops SLD}

The previous discussion provided convincing evidence for the existence of liquid drops in the size range $50-300 \mu \mathrm{m}$. This SLD mode is predominantly found during embedded cell traverses in short bursts of few seconds, respectively, a couple of hundred meters. The increase of ice particle size towards cloud base seems to be caused by riming. Whether SLD contribute significantly to the observed riming could not be documented. We only note that there seems to be an upper bound for the SLD size at about 200-300 $\mu \mathrm{m}$, the reason for that is not understood. Riming might be one explanation, contact freezing another.

\subsection{Ice accretion rates and limitations of liquid water content measurements}

We should note that for a true air speed of $80 \mathrm{~m} / \mathrm{s}$ an ice accretion rate of $\mathrm{Imm} / \mathrm{min}$ requires at least a supercooled liquid water content SLWC in $\mathrm{g} \mathrm{m}^{-3}$ of $\sim \mathrm{I} / 4.8$. Thus the measured maximum value of $3.5 \mathrm{~mm} / \mathrm{min}$ corresponds to a SLWC of $\sim 0.7 \mathrm{~g} \mathrm{~m}^{-3}$. How consistent is the observed liquid water content with the measured ice accretion rate? Figures 8, 9 and 14 show that liquid water content values of $0.25-0.3 \mathrm{~g} \mathrm{~m}^{-3}$ correspond with icing rates of $2-3.5 \mathrm{~mm} \mathrm{~min}^{-1}$. The latter, however, must have been caused, according to our above estimate of $\mathrm{I} / 4.8$, by a SLWC of $0.5-0.7 \mathrm{~g} \mathrm{~m}^{-3}$, twice as high as observed. The discrepancy is likely due to the sensitivity of the Johnson-Williams instrument which declines sharply for liquid particles larger $30 \mu \mathrm{m}$ (Gayet, 1986), implying that more SLWC was present than detected by the JohnsonWilliams instrument and, second, that the SLD contribution to the observed icing rates, though small, was underestimated, if not completely ignored. Checking the correlation of $\mathrm{LWC}_{\mathrm{JoWi}}$ and ice accretion rate during the two sequences Seq1 and Seq2, we found (not shown) a rough correlation with, however, considerable scatter. Large values of LWC may exist, as for example on March 24, but are not correlated with equivalent fluctuations in the icing rate. This can be caused by drops smaller $10 \mu \mathrm{m}$ which did not impinge on the icing cylinder. Vice versa, all icing rate values above a line given by $\mathrm{I}=4.8$ LWC must have been caused by drops not captured by the Johnson-Williams. Figure 9 emphasizes again the problem of underestimated SLWC. Not only the $\mathrm{LWC}_{\mathrm{JoWi}}$ but also the two other liquid water content measures reveal values half as large as required. One further reason might be that the icing cylinder is too close to the fuselage and within the aircraft aerodynamic boundary and thus collects more SLWC than the cloud probes beneath the wing. The problem needs further clarification with a first step following Cober et al (2001b) to correct for LWC measurements in the presence of ice particles with number concentration exceeding $1 \mathrm{~L}^{-1}$.

\subsection{Aircraft performance degradation}

The observed aircraft performance degradation of about $30 \%$ on March 24 and the required safety descent are without doubt due to the accreted ice. We observed several factors contributing to this performance degradation: (1) substantial ice accretion on the wing leading edge (see Fig. 17), (2) parts of the ice could not be removed by the pneumatic boots, especially close to the fuselage and on the adjacent upper and lower section of the wing as can be seen in Fig. 17, (3) run-back ice similar as for March 15 (Fig. 10), and (4) humps up to $40 \mathrm{~cm}$ downstream the cord. The relative contribution of the various ice accretion forms to the performance degradation, however, could not be determined. The joint occurrence of high liquid water content in the cloud drop mode and of SLD 
makes this discrimination difficult. Our flights suggest that SLD seem to contribute only with $20 \%$ to the total liquid water content and may be considered as a by-product of and correlated with high liquid water content. The impact of both factors on performance, however, is quite different and has to be determined by other means. Most of the accreted ice on the aircraft wings stems from normal cloud drops, while SLD caused run-back ice and impacted downstream the protected regions of the wings. The relative contributions of the cloud droplet and SLD modes to the observed $30 \%$ degradation loss have to be explored further.

\subsection{Summary}

In summary, the EURICE flights demonstrated the existence of SLD under conditions of embedded convection which so far where not considered as hazardous. The flights further showed the importance of mixed phase conditions. This has to be considered when the certification procedures will be revised. The coexistence of SLD and high liquid water content values in convective clouds has to be explored further. Our flights indicate that SLD might be a by-product of liquid water content maxima.

\section{Acknowledgements}

The aircraft campaign and a great part of the data evaluation were performed while both authors were affiliated with the Institut für Physik der Atmosphäre at the German Aerospace and Research Center (DLR), Oberpfaffenhofen. To perform icing research flights with the DO-228 aircraft, which has not yet been used for this purpose, and to investigate unknown and potentially hazardous atmospheric conditions was a huge challenge for pilots, technicians and researchers. The authors are grateful to all colleagues who made this piece of research possible. The flights were part of the EC-funded project EURICE. Funding is gratefully acknowledged. The fruitful cooperation with many European partners on the improvement of safety in aviation was an encouraging experience.

\section{References}

Amendola A, Mingione G, Cailhol D, Hauf T (1998) EURICE: An European effort for the improvement of in-flight aircraft icing safety. 36th Aerospace Sciences Meeting and Exhibition, January 12-15, 1998, Reno, NV

Bain M, Gayet JF (1982) Aircraft measurements of icing in supercooled and water droplet/ice crystal clouds. J Appl Meteor 21: 631-641
Biter CJ, Dye JE, Huffman D, King WD (1987) The dropsize response of the CSIRO liquid water content probe. J Atmos Ocean Tech 4: 359-367

Cober SG, Isaac GA, Strapp JW (1995) Aircraft icing measurements in East Coast winter storms. J Appl Meteor 34: 88-100

Cober SG, Strapp JW, Isaac GA (1996a) An example of supercooled drizzle droplets formed through a collision coalescence process. J Appl Meteor 35: 2250-2260

Cober SG, Isaac GA, Strapp JW, Marcotte D (1996b) Analysis of aircraft icing environments associated with supercooled drizzle. Proc. FAA Int. Conf. on Aircraft Inflight Icing, Springfield, Virginia, 6-8 May 1996, DOT/FAA/ AR-96/81, II, 1-11

Cober SG, Strapp JW, Isaac GA (2001a) Characterizations of aircraft icing environments that include supercooled large drops. J Appl Meteor 40: 1984-2002

Cober SG, Isaac GA, Korolev AV, Strapp JW (2001b) Assessing cloud-phase conditions. J Appl Meteor 40: 1967-1983

Cooper WA, Sand WR, Politovich MK, Donald LV (1984) Effects of icing on performance of a research airplane. J Aircraft 21: 708-715

Federal Aviation Administration (1999) Appendix C. Airworthiness standard: Transport category airplanes, part 25. Aeronautics and Space, Vol. 14, U.S. Code of Regulations, Office of the Federal Register, National Archives and Records Administration (available from Superintendent of Documents, U.S. Government Printing Office, Washington, DC 20402-9328)

Gayet JF (1986) Calibration of Johnson-Williams and PMSFSSP probes in a wind tunnel. J Atmos Ocean Tech 3: 381-390

Hagen M, Meischner P (2000) Estimation of rainfall parameters from polarimetric radar measurements with POLDIRAD. Phys Chem Earth (B) 25: 10-12, 849-853

Hallett J, Mossop SC (1974) Production of secondary particles during the riming process. Nature 249: 26-28

Hobbs PV, Rangno AL (1985) Ice particle concentrations in clouds. J Atmos Sci 42: 2523-2549

Hoffmann HE, Demmel J (1992) Analysis of three icing test flights reaching the aircraft-referred icing degree "severe". European Space Agency, Report ESA-TT-1254

Korolev AV, Strapp JW, Isaac GA (1998) Evaluation of accuracy of PMS optical array probes. J Atmos Ocean Tech 15: 708-720

Politovich MK (1989) Aircraft icing caused by large supercooled droplets. J Appl Meteor 28: 856-868

Politovich MK (1996) Response of a research aircraft to icing conditions and evaluation of icing severity indices. J Aircraft 33: 291-297

Pruppacher HR, Klett JD (1997) Microphysics of clouds and precipitation, 2nd ed. Dordrecht: Kluwer Academic Publishers, $954 \mathrm{pp}$

Rasmussen RM, Politovich MK, Marwitz JD, McGinley J, Smart J, Sand W, Stossmeister G, Bernstein B, Pielke R, Wesley D, Rutledge S, Elmore K, Westwater ER, Stankov B, Burrows D (1992) Winter Icing and Storms Project (WISP). Bull Amer Meteor Soc 73: 951-974 
Rasmussen RM, Geresdi I, Thompson G, Manning K, Karplus E (2000) Freezing drizzle and supercooled large droplet (SLD) formation in stably stratified layer clouds: Results from detailed microphysical simulations and implications for aircraft icing. 9th Conf. on Aviation, Range, and Aerospace Meteorology, Amer Meteor Soc, 11-15 September 2000, Orlando, FL

Rauber RM, Tokay A (1991) An explanation for the existence of supercooled water at the top of cold clouds. J Atmos Sci 48: 1005-1023

Riley JT (1998) Mixed-Phase Icing Conditions: A Review. Office of Aviation Research, Washington D.C., Final Report 20591DOT/FAA/AR-98/76, December 1998, National Technical Information Service (NTIS), Springfield, Virginia 22161

Sand WR, Biter CJ (2000) Meteorology surrounding the Roselawn accident. 9th Conf. on Aviation, Range, and Aerospace Meteorology, Amer Meteor Soc, 11-15 September 2000, Orlando, FL

Stingl S (1999) Das EURICE Flugmessexperiment Experimentbeschreibung und Analyse eines Messfluges.
Diploma thesis, Institut für Meteorologie und Klimatologie, Universität Hannover, Germany

Strapp JW, Stuart RA, Isaac GA (1996) Canadian climatology of freezing precipitation, and a detailed study using data from St. John's, Newfoundland. Proc. FAA Int. Conf. on Aircraft Inflight Icing, Springfield, Virginia, Vol. II, DOT/FAA/AR-96/81: 45-55

Vali G (1997) Cloud properties measured from aircraft - an assessment. WMO Workshop on Measurement of Cloud Properties for Forecasts of Weather, Air Quality and Climate, June 23-27, 1997, Mexico City, Mexico

Vohl O (2000) An experimental investigation of the effects of turbulence on the scavenging of aerosol particles by rain drops, and on the growth of cloud drops by collision. Diss. Johannes-Gutenberg-Universität Mainz, 2000

Authors' addresses: T. Hauf, Institut für Meteorologie und Klimatologie, Universität Hannover, Hannover, Germany (E-mail: hauf@muk.uni-hannover.de); F. Schröder, Institut für Physik der Atmosphäre, DLR Oberpfaffenhofen, Oberpfaffenhofen, Germany

Verleger: Springer-Verlag GmbH, Sachsenplatz 4-6, 1201 Wien, Austria. - Herausgeber: Prof. Dr. Reinhold Steinacker, Institut für Meteorologie und Geophysik, Universität Wien, Althanstraße 14, 1090 Wien, Austria. - Redaktion: Althanstraße 14, 1090 Wien, Austria. - Satz und Umbruch: Thomson Press (India) Ltd., Chennai. - 